\title{
James Robert Alfano, A Giant in Phytopathogenic Bacteria Effector Biology
}

\author{
Alan Collmer \\ School of Integrative Plant Science, Section of Plant Pathology and Plant-Microbe Biology, Cornell University, Ithaca, NY 14853, \\ U.S.A.
}

Accepted 7 January 2020.

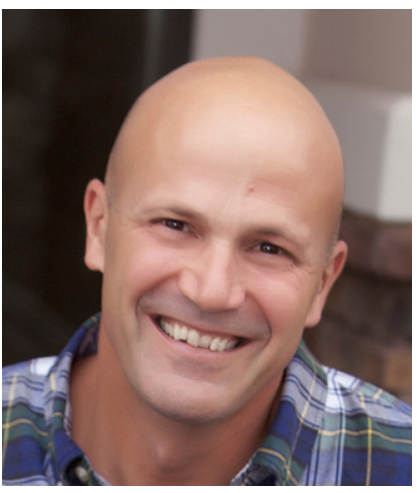

The worldwide molecular plant-microbe interactions research community was significantly diminished in November 2019 by the death of James "Jim" Robert Alfano at age 56. Jim was a giant in our field, who gained key insights into plant pathogenesis using the model bacterial pathogen Pseudomonas syringae. As a mentor, collaborator, and, above all, a friend, I know Jim's many dimensions and accomplishments and, sadly, the depth of loss being felt by the many people around the world who were touched by him. In tracing the path of Jim's career, I will emphasize the historical context and impact of his advances and, finally, the essence of the person we will so miss.

Jim was born June 2, 1963 in Burbank, California, and spent his childhood years in Simi Valley. He received his Bachelor of Science degree in Microbiology in 1986 from San Diego State University and his Ph.D. in Microbiology in 1993 from Washington State University. There, he did thesis research in the Institute of Biological Chemistry, in the lab of Michael Kahn, on biochemical genetics of intermediary metabolism of Rhizobium meliloti (Alfano and Kahn 1993). That work began Jim's lifelong interest in bacteria that interact with plants. From 1993 to $1997 \mathrm{Jim}$ was a postdoctoral research associate in my lab in the Department of Plant Pathology at Cornell University, where he launched his career work with $P$. syringae.

Jim made important contributions to a paradigm shift in our understanding of the cellular location and nature of events underlying plant interactions with $P$. syringae (and, as found subsequently, with other hemibiotrophic/biotrophic bacterial, fungal, and oomycete pathogens). That is, i) P. syringae avr (avirulence) genes, previously discovered by the infection phenotype they confer in resistant plant varieties, encode proteins that are injected into plant cells, ii) horizontal acquisition of a pathogenicity island encoding the protein injector system was seminal in the evolution of $P$. syringae and its many pathovars, iii) genomic sequence signatures could be used to comprehensively identify the injected proteins, iv) these proteins predominantly suppress plant immunity, and v) they do so

${ }^{\dagger}$ Corresponding author: A. Collmer; arc2@ cornell.edu

(c) 2020 The American Phytopathological Society by disrupting specific immune system proteins via diverse and sometimes novel biochemical activities. As I will explain below, this chain of discoveries by Jim occurred in the context of explosive progress in multiple labs studying bacterial pathogens of animals and plants, which was sparked by the new tools of transposon mutagenesis, molecular cloning, and, eventually, genomics. Jim sustained his role as a pioneer for 25 years in this fast-paced field through his choice of important problems, his creative and fearless experimentation, and his infectiously open enthusiasm for science.

Jim arrived at Cornell in March 1993 with a tall athleticism and an easy laugh coupled with a strong background in molecular microbiology and a driving curiosity. He began his work with $P$. syringae by confronting the paradoxical activities of $P$. syringae hrp genes in eliciting the hypersensitive response (HR) and trafficking different classes of proteins. The hrp (HR and pathogenesis) gene cluster had previously been discovered, through transposon mutagenesis of $P$. syringae pv. phaseolicola, in Nickolas Panopoulos's lab at Berkeley (Lindgren et al. 1986), and our lab had subsequently cloned a hrp gene cluster (cosmid pHIR11) from P. syringae pv. syringae that was sufficient for the nonpathogen Pseudomonas fluorescens to elicit the HR in tobacco (Huang et al. 1988). pHIR11 was found to encode a "harpin" (Wei et al. 1992) protein, designated HrpZ, which was secreted in culture in a manner dependent on $h r p H$ (now designated $h r c C$ ), an early $h r p$ gene to be studied (He et al. 1993). HrpZ was both sufficient (as an isolated protein) and necessary (based on mutagenesis) for HR elicitation (He et al. 1993). These findings demonstrated that the hrp genes encoded a protein secretion system and suggested that HrpZ was a natural elicitor of the HR.

To sense the early state of the field in 1993, it is noteworthy that genes similar to $h r p H$ had just recently been observed in several genera of phytopathogenic bacteria and also had been shown necessary for the secretion of Yops (Yersinia outer proteins) by human pathogenic Yersinia spp. (Fenselau et al. 1992; Gough et al. 1992; Huang et al. 1992; Michiels et al. 1990). This secretion system, which was central to the virulence of many proteobacteria pathogens of plants and animals would soon become universally known as the type III secretion system (T3SS) (Salmond 1994). Jim's detailed genetic analysis of pHIR11 and associated secretion and HR phenotypes upended our early understanding of what phytopathogen T3SSs were doing. He found that mutants deficient in a pHIR11 gene now designated hopAl (Hrp outer protein) produced and secreted wild-type levels of HrpZ but nevertheless failed to elicit the HR. This led to the hypothesis that HrpZ was actually a "helper" for the delivery of HopA1, which was the actual elicitor (Alfano et al. 1996). Moreover, hopAl was similar to 
several $a v r$ genes that had been cloned since 1984 in being essential for HR elicitation in a resistant plant but lacking a role in the Hrp secretion system (Alfano et al. 1996; Keen 1990; Staskawicz et al. 1984). Furthermore, the Yersinia T3SS had just been shown to translocate Yops into animal cells in a contact-dependent manner (Rosqvist et al. 1994; Sory and Cornelis 1994), and recently cloned plant genes that interacted in a "gene-for-gene" manner with $P$. syringae avr genes encoded cytoplasmic proteins (Bent et al. 1994; Martin et al. 1993; Mindrinos et al. 1994). Jim marshalled multiple lines of evidence (in collaboration with Sheng Yang He's lab at the Department of Energy, Plant Research Laboratory, Michigan State University) showing that AvrB (the product of a P. syringae pv. glycinea gene with an Avr phenotype in both soybean and Arabidopsis) as well as HopA were translocated in a T3SSdependent manner into plant cells, in which their biological activity was then experimentally verified (Alfano et al. 1997; Gopalan et al. 1996).

The proteins injected by the T3SS of plant and animal pathogens soon became universally known as effectors, and the focus with phytopathogens shifted to the systematic identification of effectors. This was uniquely challenging for those of us working with phytopathogens because effectors were poorly secreted (if at all) in culture, and, though collectively essential for virulence, they were invisible in mutant screens for reduced virulence because of functional redundancies (Galán and Collmer 1999). To overcome these challenges, Jim made two major advances by using genome sequence information to identify effector gene candidates.

Jim began this new research phase at Cornell, but he brought it to fruition with his own lab, which he launched in the Department of Biological Sciences at the University of Nevada, Las Vegas in 1997 and then moved to the Plant Science Initiative and Department of Plant Pathology at the University of NebraskaLincoln (UNL) in 2000. Jim was not alone in this venture because, at Cornell, he met Karin van Dijk, a student in the Graduate Field of Plant Pathology, who was studying fatty acid uptake and beta-oxidation in the biocontrol bacterium Enterobacter cloacae. Karin would become Jim's partner in science, parenthood, and life. She initiated Jim's career-long exploration of the environmental and genetic factors controlling the traffic of different classes of proteins through the T3SS and into plant cells (Petnicki-Ocwieja et al. 2005; van Dijk et al. 1999, 2002) and joined the faculty of Creighton University and then UNL, where she is now an Associate Professor of Biochemistry.

Jim's first advance in genome sequence-based identification of effectors involved sequencing and functionally analyzing the $h r p$ gene clusters and flanking sequences in three model strains of $P$. syringae, including $P$. syringae pv. tomato DC3000. This work revealed that $h r p$ genes are part of a tripartite pathogenicity island that includes an exchangeable effector locus and a conserved effector locus (CEL) harboring core effector genes (with many more effector genes somewhere else in the genome) (Alfano et al. 2000). It also defined the genomic insertion point of the pathogenicity island and documented the centrality of the acquisition event in the evolution of $P$. syringae virulence. Furthermore, a $P$. syringae pv. tomato DC3000 CEL mutant lacking three putative effectors was strongly reduced in virulence (Alfano et al. 2000). The CEL deletion mutant proved useful in revealing functional redundancies within the effector repertoire and the role of effectors HopM1 and AvrE in disrupting vesicle trafficking and promoting watersoaking, an important process in pathogenesis (Kvitko et al. 2009; Nomura et al. 2006; Xin et al. 2016, 2018).

Jim's pioneering work on the Hrp system and especially the $P$. syringae pv. tomato DC3000 Hrp pathogenicity island was foundational to a 2000 multi-institutional award from the
National Science Foundation Plant Genome Research Program to Cornell and three other universities, the United States Department of Agriculture Agricultural Research Service, the Boyce Thompson Institute, and The Institute for Genomic Research to sequence and functionally characterize the genome of DC3000. Jim was a co-investigator and contributed to a remarkable 21 project-supported publications between 2002 and 2007. It was in the context of this project that Jim made his second major advance in the genomic search for effector genes. Specifically, Jim and his lab group led an iterative approach involving sequence-based computational and experimental methods to identify many more DC3000 effector candidates, which characteristically possessed Hrp-box promoter sequences and N-terminal T3SS-associated amino acid patterns and were demonstrably activated by the HrpL alternative sigma factor and translocated into plant cells by the T3SS (Fouts et al. 2002; Petnicki-Ocwieja et al. 2002).

During this period of effector prospecting, Jim's group also developed pLN18, a $\triangle$ hopAl "effectorless" derivative of pHIR11, which enabled our two labs to further define the T3SS targeting domain in effectors using C-terminal Cya (adenylate cyclase) translocation reporter fusions (Schechter et al. 2004). Further iterations and refinements of this approach eventually expanded the repertoire to 29 actively deployed effectors (Wei and Collmer 2018; Wei et al. 2015). However, at this point in the project, Jim's lab moved on to the next major challenge of systematically seeking virulence functions for effectors.

We were aware of isolated examples of effectors able to suppress the HR avirulence activity of other effectors or even of a domain within the same effector (Abramovitch et al. 2003; Jackson et al. 1999; Tsiamis et al. 2000). The relatively large size of the DC3000 effector repertoire raised the possibility that HR suppressors could be common components of functional repertoires. To test this hypothesis, Jim's group systematically expressed DC3000 effector clones in P. fluorescens(pHIR11) to identify those that suppressed the HR elicited in tobacco and Arabidopsis by HopA1. Remarkably, six of 19 possessed such activity (Jamir et al. 2004). Jim's research subsequently expanded the number of effectors tested, revealing that the majority of DC3000 effectors possess HR-suppressive activity (Guo et al. 2009).

$P$. syringae pv. tomato DC3000 was a model pathogen, in part, because of its virulence in two experimentally amenable plants, Arabidopsis and tomato. But DC3000 elicited a typical HR-associated avirulence when inoculated into Nicotiana benthamiana, a plant that was becoming increasingly attractive as an alternative model for research into plant-microbe interactions (Goodin et al. 2008). Jim's insights and collaborative work led to a $N$. benthamiana-DC3000 pathosystem that had a major impact on further development of DC3000 as a model pathogen and a probe for plant immunity. In a joint effort between Jim's and my groups, effectorless pLN18 was used to comprehensively identify DC3000 effectors that could elicit the HR in $N$. benthamiana and, thus, were candidate Avr determinants (Schechter et al. 2004; Wei et al. 2007). Remarkably, deletion of one of these candidate Avr genes, hopQ1-1, enabled $P$. syringae pv. tomato DC3000 to become fully virulent in $N$. benthamiana (Wei et al. 2007). DC3000 $\Delta$ hopQ1-1 derivatives were then constructed with deletions in the subset of effector genes that occur in several clusters in the genome, and these mutants were assayed for reductions in virulence in Arabidopsis, tomato, and N. benthamiana to begin the process of disassembling the effector repertoire and its internal redundancy (Wei et al. 2007).

With these major contributions to the overall structure and function of the $P$. syringae pv. tomato DC3000 effector repertoire achieved, Jim's group then focused on molecular mechanisms 
underlying the activity of individual effectors. This work largely involved the Arabidopsis-DC3000 pathosystem and was informed by the recently formalized conceptual framework of the two-tiered innate immune system of plants (Jones and Dangl 2006): i) pathogen (or microbe)-associated molecular patterns elicit pattern-triggered immunity (PTI) upon detection by surface-arrayed pattern-recognition receptors and ii) effectors, injected in part to suppress PTI, can instead betray the pathogen to intracellular nucleotide-binding leucine-rich repeat proteins resulting in HR-associated effector-triggered immunity (ETI). Thus, effectors can have complex roles in plant interactions as suppressors of PTI, elicitors of ETI, or even (as discussed above) as suppressors of ETI.

Jim's lab focused on several of the $P$. syringae pv. tomato DC3000 effectors: HopU1, HopAO1, HopG1, HopD1, HopK1, HopE1, HopB1, and HopO1-1 (earlier names can be found online on the Pseudomonas Plant Interaction Pseudomonas syringae Genome Resources page). Jim astutely exploited an array of clues to anchor a molecular assault on a given effector's function, such as biochemical activity predicted from sequence, a plant protein interactor, or an intriguing subcellular localization pattern in plant cells. The subsequent investigations were characteristically thorough as his group strove to identify biochemical activities and critical amino acids in both the effector and the target protein, to verify biological relevance with both bacterial and plant mutants, and to place the effectortarget interaction in the context of emerging models of PTI, ETI, and their associated signaling pathways and defense outputs. The high quality of Jim's effector publications has made them solid building blocks for the future of the field.

HopU1 is a notable example among the investigated effectors. The effector was found through genomics, and its sequence predicted ADP-ribosyltransferase activity (PetnickiOcwieja et al. 2002). Jim's group demonstrated that HopU1 functioned as a mono-ADP-ribosyltransferase (mADP-RT) to promote virulence (Fu et al. 2007). Although there was precedence for mADP-RT activity in some animal pathogen effectors, this was the first report of such an activity in a phytopathogen and the first report for an effector from any pathogen targeting RNA-binding proteins. Importantly, this finding predicted that type III effectors can manipulate posttranscriptional control of host RNA as a means to suppress defense. Jim's group, in collaboration with Cyril Zipfel at the Sainsbury Laboratory, confirmed this prediction by demonstrating that HopU1 interferes with glycine-rich RNA-binding protein GRP7 interaction with pattern recognition receptor transcripts. In so doing, HopU1 diminishes production of the flagellin receptor FLS2, which is important for plant immunity to bacteria (Nicaise et al. 2013). Moreover, in collaboration with Yanhui $\mathrm{Xu}$ of Fudan University, the structural basis of HopU1 disruption of GRP7 was determined to involve two protruding loops that were unique to HopU1 among known mADP-RTs and a conserved residue, Arg-49, in the RNArecognition motif of GRP7 (Jeong et al. 2011). HopU1 is one of the best characterized phytopathogen type III effectors, and Jim's work yielded important insights into its role ranging from immunity mechanisms to effector evolution.

Investigations of other $P$. syringae pv. tomato DC3000 effectors yielded a panoply of other insights, with representative examples highlighted here. In relatively early work, HopAO1 was found to have protein tyrosine phosphatase activity with a catalytically active Cys residue being essential for the ability of the effector to block ETI-associated programmed cell death (Espinosa et al. 2003). HopG1 is the first phytopathogen effector shown to localize to mitochondria, which is required for its activity in suppressing both PTI and ETI (Block et al. 2010). HopD1 interacts with Arabidopsis membrane-tethered transcription factor NTL9, and the use of reciprocal plant and bacterial mutants revealed both the importance of NTL9 in immunity and of HopD1 in its suppression (Block et al. 2014). HopK1 uses a cleavable transit peptide to localize to chloroplasts, and this localization is essential for PTI suppression and promotion of virulence ( $\mathrm{Li}$ et al. 2014). HopE1 uses plant calmodulin as a cofactor to target microtubule-associated protein 65 , an important component of the microtubule network, thus dissociating it from microtubules and suppressing PTI (Guo et al. 2016). HopB 1 is encoded in the $P$. syringae pv. tomato DC 3000 exchangeable effector locus and was used by Jim's lab to explore the T3SS translocation process (Fu et al. 2006). A collaboration with Jian-Min Zhou, at the State Key Laboratory of Plant Genomics of the Chinese Academy of Sciences, has recently revealed that HopB1 acts as a serine protease to cleave the coreceptor BAK1 and thereby block FLS2-dependent early PTI responses to bacterial flagellin but, remarkably, only when activated by the flg22 flagellin peptide (Li et al. 2016). HopO1-1 will be discussed below.

Jim's group also continued at UNL their work on mechanisms by which the T3SS delivers effectors. They identified several chaperone proteins that function in $P$. syringae pv. tomato DC3000 for the dedicated delivery of cognate effectors (Guo et al. 2005; Shan et al. 2004; van Dijk et al. 2002; Wehling et al. 2004). They showed that HrpK is secreted by the T3SS and appears to function as a translocator of effectors across the host plasma membrane (Petnicki-Ocwieja et al. 2005). Finally, HrpJ functions as its animal pathogen homologs in controlling T3SS substrate traffic (Fu et al. 2006), and remarkably, this protein, which is delivered into plant cells by the T3SS, can also suppress immune responses (Crabill et al. 2012).

Jim developed synergistic and productive collaborations with many other research groups throughout his career. Among his most recent collaborations, two are particularly noteworthy. First, a joint effort led by Renier A. L. van der Hoorn at the University of Oxford yielded the first $P$. syringae pv. tomato DC3000 apoplastic effector, a small secreted protein that promotes virulence by inhibiting tomato immune proteases in the extracellular interface of bacteria and plant cells (Shindo et al. 2016). Second, a collaborative effort led by Sheng Yang He at the Department of Energy, Plant Research Laboratory, Michigan State University, has revealed that HopO1-1 physically interacts with and destabilizes at least one plasmodesmatalocated protein, PDLP7, thus increasing molecular flux between neighboring leaf cells and promoting bacterial spread-with several lines of evidence suggesting that HopO1-1 uses its mADP-RT activity to destabilize PDLP7 (Aung et al. 2019). Importantly, these two reports widen the spatial scope of $P$. syringae pv. tomato DC3000 molecular manipulations of plants.

Jim's broad view of the field and his gift for clear communication made him an ideal partner in writing a long series of review articles with a succession of coauthors. The titles of the first and last of these reviews capture the progress our field has made since Jim began working with $P$. syringae in 1993 . The first, "Bacterial pathogens in plants: Life up against the wall," sketched the outlines of a model for pathogenesis encompassing various phytopathogen lifestyles and the newly discovered ability of the Hrp system to inject effector proteins (Alfano and Collmer 1996). The last review, "Plant targets for Pseudomonas syringae type III effectors: Virulence targets or guarded decoys?", shows how remarkably the research focus had deepened into the molecular activities of the injected effectors, specifically into the complex web of effector interactions with plant targets that determines infection outcomes (Block and Alfano 2011).

Jim also had broad interests in science education, and he initiated the Undergraduate Program in Microbiology at UNL, 
for which he was Director since it started in 2011. And through his research program, he mentored and launched a thriving new generation of students and postdocs in science careers. Jim's broad perspective on the field and his scholarly rigor also made him a highly regarded member of multiple editorial boards, grant review panels, and conference organizing committees. Jim was named a Charles Bessey Professor at UNL in 2010 and was elected as a fellow in the American Phytopathological Society in 2011, the American Association for the Advancement of Science in 2012, and the American Academy of Microbiology in 2015.

The announcement of Jim's death triggered an outpouring of tributes from around the world that were collected in the December 2019 issue of IS-MPMI Interactions. Also, many loving remembrances from the UNL community were shared at a celebration of life at The George W. Beadle Center at UNL on December 15 . Jim seemed to touch so many so deeply because of his infectious enthusiasm for life (and science) coupled with his genuinely interested caring for other people. Our Cornell lab family memories of Jim from his postdoctoral days began with him arriving in a ski jacket, filling the frame of the lab door, and as one lab member recalls, "looking as though he could have pushed his rental truck and the Jeep it was towing over the Rockies himself." Jim did indeed enjoy the outdoors and sports, and through that infused high spirits into many scientific gatherings, for example, with the soccer games that became a tradition at international Pseudomonas syringae conferences. But Jim also had a critical eye for good novels and movies, was broadly curious about politics and the world, and loved nature. Jim also had a more sensitive side that came to the fore when he was with his wife, Karin, and then further with the birth of their daughter, Isabella, of whom he was so proud. Jim's many dimensions and personal depth fostered close friendships across the UNL and international research communities. As summarized by one international tribute, "He was a giant indeed, but also one of the kindest colleagues in the field." The loss of Jim as a scientist leaves our community diminished. The loss of Jim as friend leaves us devastated.

\section{LITERATURE CITED}

Abramovitch, R. B., Kim, Y. J., Chen, S., Dickman, M. B., and Martin, G. B. 2003. Pseudomonas type III effector AvrPtoB induces plant disease susceptibility by inhibition of host programmed cell death. EMBO J. 22:60-69.

Alfano, J. R., Bauer, D. W., Milos, T. M., and Collmer, A. 1996. Analysis of the role of the Pseudomonas syringae pv. syringae HrpZ harpin in elicitation of the hypersensitive response in tobacco using functionally non-polar hrpZ deletion mutations, truncated HrpZ fragments, and hrmA mutations. Mol. Microbiol. 19:715-728.

Alfano, J. R., Charkowski, A. O., Deng, W.-L., Badel, J. L., Petnicki-Ocwieja, T., van Dijk, K., and Collmer, A. 2000. The Pseudomonas syringae Hrp pathogenicity island has a tripartite mosaic structure composed of a cluster of type III secretion genes bounded by exchangeable effector and conserved effector loci that contribute to parasitic fitness and pathogenicity in plants. Proc. Natl. Acad. Sci. U.S.A. 97:4856-4861.

Alfano, J. R., and Collmer, A. 1996. Bacterial pathogens in plants: Life up against the wall. Plant Cell 8:1683-1698.

Alfano, J. R., and Kahn, M. L. 1993. Isolation and characterization of a gene coding for a novel aspartate aminotransferase from Rhizobium meliloti. J. Bacteriol. 175:4186-4196.

Alfano, J. R., Klm, H. S., Delaney, T. P., and Collmer, A. 1997. Evidence that the Pseudomonas syringae pv. syringae hrp-linked hrmA gene encodes an Avr-like protein that acts in an hrp-dependent manner within tobacco cells. Mol. Plant-Microbe Interact. 10:580-588.

Aung, K., Kim, P., Li, Z., Joe, A., Kvitko, B. H., Alfano, J. R., and He, S. Y. 2019. Pathogenic bacteria target plant plasmodesmata to colonize and invade surrounding tissues. Plant Cell doi:10.1105/tpc.19.00707.

Bent, A. F., Kunkel, B. N., Dahlbeck, D., Brown, K. L., Schmidt, R., Giraudat, J., Leung, J., and Staskawicz, B. J. 1994. RPS2 of Arabidopsis thaliana: A leucine-rich repeat class of plant disease resistance genes. Science 265:1856-1860.
Block, A., and Alfano, J. R. 2011. Plant targets for Pseudomonas syringae type III effectors: Virulence targets or guarded decoys? Curr. Opin. Microbiol. 14:39-46.

Block, A., Guo, M., Li, G., Elowsky, C., Clemente, T. E., and Alfano, J. R. 2010. The Pseudomonas syringae type III effector HopG1 targets mitochondria, alters plant development and suppresses plant innate immunity. Cell. Microbiol. 12:318-330.

Block, A., Toruño, T. Y., Elowsky, C. G., Zhang, C., Steinbrenner, J., Beynon, J., and Alfano, J. R. 2014. The Pseudomonas syringae type III effector HopD1 suppresses effector-triggered immunity, localizes to the endoplasmic reticulum, and targets the Arabidopsis transcription factor NTL9. New Phytol. 201:1358-1370.

Crabill, E., Karpisek, A., and Alfano, J. R. 2012. The Pseudomonas syringae HrpJ protein controls the secretion of type III translocator proteins and has a virulence role inside plant cells. Mol. Microbiol. 85: 225-238.

Espinosa, A., Guo, M., Tam, V. C., Fu, Z. Q., and Alfano, J. R. 2003. The Pseudomonas syringae type III-secreted protein HopPtoD2 possesses protein tyrosine phosphatase activity and suppresses programmed cell death in plants. Mol. Microbiol. 49:377-387.

Fenselau, S., Balbo, I., and Bonas, U. 1992. Determinants of pathogenicity in Xanthomonas campestris pv. vesicatoria are related to proteins involved in secretion in bacterial pathogens of animals. Mol. PlantMicrobe Interact. 5:390-396.

Fouts, D. E., Abramovitch, R. B., Alfano, J. R., Baldo, A. M., Buell, C. R., Cartinhour, S., Chatterjee, A. K., D'Ascenzo, M., Gwinn, M. L., Lazarowitz, S. G., Lin, N. C., Martin, G. B., Rehm, A. H., Schneider, D. J., van Dijk, K., Tang, X., and Collmer, A. 2002. Genomewide identification of Pseudomonas syringae pv. tomato DC3000 promoters controlled by the HrpL alternative sigma factor. Proc. Natl. Acad. Sci. U.S.A. 99:2275-2280.

Fu, Z. Q., Guo, M., and Alfano, J. R. 2006. Pseudomonas syringae HrpJ is a type III secreted protein that is required for plant pathogenesis, injection of effectors, and secretion of the HrpZ1 Harpin. J. Bacteriol. 188: 6060-6069.

Fu, Z. Q., Guo, M., Jeong, B. R., Tian, F., Elthon, T. E., Cerny, R. L., Staiger, D., and Alfano, J. R. 2007. A type III effector ADP-ribosylates RNA-binding proteins and quells plant immunity. Nature 447:284-288.

Galán, J. E., and Collmer, A. 1999. Type III secretion machines: Bacterial devices for protein delivery into host cells. Science 284:1322-1328.

Goodin, M. M., Zaitlin, D., Naidu, R. A., and Lommel, S. A. 2008. Nicotiana benthamiana: Its history and future as a model for plantpathogen interactions. Mol. Plant-Microbe Interact. 21:1015-1026.

Gopalan, S., Bauer, D. W., Alfano, J. R., Loniello, A. O., He, S. Y., and Collmer, A. 1996. Expression of the Pseudomonas syringae avirulence protein AvrB in plant cells alleviates its dependence on the hypersensitive response and pathogenicity ( $\mathrm{Hrp}$ ) secretion system in eliciting genotype-specific hypersensitive cell death. Plant Cell 8:1095-1105.

Gough, C. L., Genin, S., Zischek, C., and Boucher, C. A. 1992. hrp genes of Pseudomonas solanacearum are homologous to pathogenicity determinants of animal pathogenic bacteria and are conserved among plant pathogenic bacteria. Mol. Plant-Microbe Interact. 5:384-389.

Guo, M., Chancey, S. T., Tian, F., Ge, Z., Jamir, Y., and Alfano, J. R. 2005. Pseudomonas syringae type III chaperones ShcO1, ShcS1, and ShcS2 facilitate translocation of their cognate effectors and can substitute for each other in the secretion of HopO1-1. J. Bacteriol. 187:4257-4269.

Guo, M., Kim, P., Li, G., Elowsky, C. G., and Alfano, J. R. 2016. A bacterial effector co-opts calmodulin to target the plant microtubule network. Cell Host Microbe 19:67-78.

Guo, M., Tian, F., Wamboldt, Y., and Alfano, J. R. 2009. The majority of the type III effector inventory of Pseudomonas syringae pv. tomato DC3000 can suppress plant immunity. Mol. Plant-Microbe Interact. 22:1069-1080.

He, S. Y., Huang, H.-C., and Collmer, A. 1993. Pseudomonas syringae pv. syringae harpin ${ }_{\text {Pss: }}$ A protein that is secreted via the Hrp pathway and elicits the hypersensitive response in plants. Cell 73:1255-1266.

Huang, H.-C., He, S. Y., Bauer, D. W., and Collmer, A. 1992. The Pseudomonas syringae pv. syringae $61 \mathrm{hrpH}$ product, an envelope protein required for elicitation of the hypersensitive response in plants. J. Bacteriol. 174:6878-6885.

Huang, H.-C., Schuurink, R., Denny, T. P., Atkinson, M. M., Baker, C. J., Yucel, I., Hutcheson, S. W., and Collmer, A. 1988. Molecular cloning of a Pseudomonas syringae pv. syringae gene cluster that enables Pseudomonas fluorescens to elicit the hypersensitive response in tobacco plants. J. Bacteriol. 170:4748-4756.

Jackson, R. W., Athanassopoulos, E., Tsiamis, G., Mansfield, J. W., Sesma, A., Arnold, D. L., Gibbon, M. J., Murillo, J., Taylor, J. D., and Vivian, A 1999. Identification of a pathogenicity island, which contains genes for virulence and avirulence, on a large native plasmid in the bean pathogen 
Pseudomonas syringae pathovar phaseolicola. Proc. Natl. Acad. Sci. U.S.A. 96:10875-10880.

Jamir, Y., Guo, M., Oh, H.-S., Petnicki-Ocwieja, T., Chen, S., Tang, X., Dickman, M. B., Collmer, A., and Alfano, J. R. 2004. Identification of Pseudomonas syringae type III effectors that can suppress programmed cell death in plants and yeast. Plant J. 37:554-565.

Jeong, B. R., Lin, Y., Joe, A., Guo, M., Korneli, C., Yang, H., Wang, P., Yu, M., Cerny, R. L., Staiger, D., Alfano, J. R., and Xu, Y. 2011. Structure function analysis of an ADP-ribosyltransferase type III effector and its RNA-binding target in plant immunity. J. Biol. Chem. 286: 43272-43281.

Jones, J. D. G., and Dangl, J. L. 2006. The plant immune system. Nature 444:323-329.

Keen, N. T. 1990. Gene-for-gene complementarity in plant-pathogen interactions. Annu. Rev. Genet. 24:447-463.

Kvitko, B. H., Park, D. H., Velásquez, A. C., Wei, C.-F., Russell, A. B., Martin, G. B., Schneider, D. J., and Collmer, A. 2009. Deletions in the repertoire of Pseudomonas syringae pv. tomato DC3000 type III secretion effector genes reveal functional overlap among effectors. PLoS Pathog. 5:e1000388.

Li, G., Froehlich, J. E., Elowsky, C., Msanne, J., Ostosh, A. C., Zhang, C., Awada, T., and Alfano, J. R. 2014. Distinct Pseudomonas type-III effectors use a cleavable transit peptide to target chloroplasts. Plant J. 77: 310-321.

Li, L., Kim, P., Yu, L., Cai, G., Chen, S., Alfano, J. R., and Zhou, J. M. 2016. Activation-dependent destruction of a co-receptor by a Pseudomonas syringae effector dampens plant immunity. Cell Host Microbe 20: 504-514.

Lindgren, P. B., Peet, R. C., and Panopoulos, N. J. 1986. Gene cluster of Pseudomonas syringae pv. "phaseolicola" controls pathogenicity of bean plants and hypersensitivity of nonhost plants. J. Bacteriol. 168:512-522.

Martin, G. B., Brommonschenkel, S. H., Chunwongse, J., Frary, A., Ganal, M. W., Spivey, R., Wu, T., Earle, E. D., and Tanksley, S. D. 1993. Mapbased cloning of a protein kinase gene conferring disease resistance in tomato. Science 262:1432-1436.

Michiels, T., Wattiau, P., Brasseur, R., Ruysschaert, J.-M., and Cornelis, G. 1990. Secretion of Yop proteins by Yersiniae. Infect. Immun. 58:2840-2849.

Mindrinos, M., Katagiri, F., Yu, G.-L., and Ausubel, F. M. 1994. The A. thaliana disease resistance gene RPS2 encodes a protein containing a nucleotide-binding site and leucine-rich repeats. Cell 78:1089-1099.

Nicaise, V., Joe, A., Jeong, B. R., Korneli, C., Boutrot, F., Westedt, I., Staiger, D., Alfano, J. R., and Zipfel, C. 2013. Pseudomonas HopU1 modulates plant immune receptor levels by blocking the interaction of their mRNAs with GRP7. EMBO J. 32:701-712.

Nomura, K., Debroy, S., Lee, Y. H., Pumplin, N., Jones, J., and He, S. Y. 2006. A bacterial virulence protein suppresses host innate immunity to cause plant disease. Science 313:220-223.

Petnicki-Ocwieja, T., Schneider, D. J., Tam, V. C., Chancey, S. T., Shan, L., Jamir, Y., Schechter, L. M., Janes, M. D., Buell, C. R., Tang, X., Collmer, A., and Alfano, J. R. 2002. Genomewide identification of proteins secreted by the Hrp type III protein secretion system of Pseudomonas syringae pv. tomato DC3000. Proc. Natl. Acad. Sci. U.S.A. 99:7652-7657.

Petnicki-Ocwieja, T., van Dijk, K., and Alfano, J. R. 2005. The hrpKoperon of Pseudomonas syringae pv. tomato DC3000 encodes two proteins secreted by the type III (Hrp) protein secretion system: HopB1 and HrpK, a putative type III translocator. J. Bacteriol. 187:649-663.

Rosqvist, R., Magnusson, K. E., and Wolf-Watz, H. 1994. Target cell contact triggers expression and polarized transfer of Yersinia YopE cytotoxin into mammalian cells. EMBO J. 13:964-972.

Salmond, G. P. C. 1994. Secretion of extracellular virulence factors by plant pathogenic bacteria. Annu. Rev. Phytopathol. 32:181-200.
Schechter, L. M., Roberts, K. A., Jamir, Y., Alfano, J. R., and Collmer, A. 2004. Pseudomonas syringae type III secretion system targeting signals and novel effectors studied with a Cya translocation reporter. J. Bacteriol. 186:543-555.

Shan, L., Oh, H. S., Chen, J., Guo, M., Zhou, J., Alfano, J. R., Collmer, A., Jia, X., and Tang, X. 2004. The HopPtoF locus of Pseudomonas syringae pv. tomato DC3000 encodes a type III chaperone and a cognate effector. Mol. Plant-Microbe Interact. 17:447-455.

Shindo, T., Kaschani, F., Yang, F., Kovács, J., Tian, F., Kourelis, J., Hong, T. N., Colby, T., Shabab, M., Chawla, R., Kumari, S., Ilyas, M., Hörger, A. C., Alfano, J. R., and van der Hoorn, R. A. 2016. Screen of nonannotated small secreted proteins of Pseudomonas syringae reveals a virulence factor that inhibits tomato immune proteases. PLoS Pathog. 12:e1005874.

Sory, M.-P., and Cornelis, G. R. 1994. Translocation of a hybrid YopEadenylate cyclase from Yersinia enterocolitica into HeLa cells. Mol. Microbiol. 14:583-594.

Staskawicz, B. J., Dahlbeck, D., and Keen, N. T. 1984. Cloned avirulence gene of Pseudomonas syringae pv. glycinea determines race-specific incompatibility on Glycine max (L.) Merr. Proc. Natl. Acad. Sci. U.S.A. 81:6024-6028.

Tsiamis, G., Mansfield, J. W., Hockenhull, R., Jackson, R. W., Sesma, A., Athanassopoulos, E., Bennett, M. A., Stevens, C., Vivian, A., Taylor, J. D., and Murillo, J. 2000. Cultivar-specific avirulence and virulence functions assigned to avrPphF in Pseudomonas syringae pv. phaseolicola, the cause of bean halo-blight disease. EMBO J. 19:3204-3214.

van Dijk, K., Fouts, D. E., Rehm, A. H., Hill, A. R., Collmer, A., and Alfano, J. R. 1999. The Avr (effector) proteins HrmA (HopPsyA) and AvrPto are secreted in culture from Pseudomonas syringae pathovars via the Hrp (type III) protein secretion system in a temperature- and $\mathrm{pH}-$ sensitive manner. J. Bacteriol. 181:4790-4797.

van Dijk, K., Tam, V. C., Records, A. R., Petnicki-Ocwieja, T., and Alfano, J. R. 2002. The ShcA protein is a molecular chaperone that assists in the secretion of the HopPsyA effector from the type III (Hrp) protein secretion system of Pseudomonas syringae. Mol. Microbiol. 44:1469-1481.

Wehling, M. D., Guo, M., Fu, Z. Q., and Alfano, J. R. 2004. The Pseudomonas syringae HopPtoV protein is secreted in culture and translocated into plant cells via the type III protein secretion system in a manner dependent on the ShcV type III chaperone. J. Bacteriol. 186: 3621-3630.

Wei, C.-F., Kvitko, B. H., Shimizu, R., Crabill, E., Alfano, J. R., Lin, N.-C., Martin, G. B., Huang, H.-C., and Collmer, A. 2007. A Pseudomonas syringae pv. tomato DC3000 mutant lacking the type III effector HopQ11 is able to cause disease in the model plant Nicotiana benthamiana. Plant J. 51:32-46.

Wei, H.-L., Chakravarthy, S., Mathieu, J., Helmann, T. C., Stodghill, P., Swingle, B., Martin, G. B., and Collmer, A. 2015. Pseudomonas syringae pv. tomato DC3000 type III secretion effector polymutants reveal an interplay between HopAD1 and AvrPtoB. Cell Host Microbe 17:752-762.

Wei, H. L., and Collmer, A. 2018. Defining essential processes in plant pathogenesis with Pseudomonas syringae pv. tomato DC3000 disarmed polymutants and a subset of key type III effectors. Mol. Plant Pathol. 19: 1779-1794.

Wei, Z.-M., Laby, R. J., Zumoff, C. H., Bauer, D. W., He, S. Y., Collmer, A., and Beer, S. V. 1992. Harpin, elicitor of the hypersensitive response produced by the plant pathogen Erwinia amylovora. Science 257:85-88.

Xin, X. F., Kvitko, B., and He, S. Y. 2018. Pseudomonas syringae: What it takes to be a pathogen. Nat. Rev. Microbiol. 16:316-328.

Xin, X. F., Nomura, K., Aung, K., Velásquez, A. C., Yao, J., Boutrot, F., Chang, J. H., Zipfel, C., and He, S. Y. 2016. Bacteria establish an aqueous living space in plants crucial for virulence. Nature 539:524-529. 